\title{
Emotional Intelligence, Psychological Adjustment and Academic Achievement among Female Students with and without Social Learning Difficulties in Najran
}

\author{
Mervat Ragab Saber \\ Assistant Professor of Special Education, College of Education \\ University of Najran, KSA \\ E-mail: dr_mervetragab@yahoo.com
}

The research is funded by the Deanship of the Scientific Research at Najran University

(NU/SHED/163)

Received: July 14, 2016 Accepted: August 15, 2016 Published: September 04, 2016

doi:10.5296/ijld.v6i3.9981 URL: http://dx.doi.org/10.5296/ ijld.v6i3.9981

\begin{abstract}
The current study aims to investigate the relationship between emotional intelligence, psychological adjustment and academic achievement among female students with and without social learning difficulties in Najran, Saudi Arabia, and to identify if there are statistically significant differences in the level of emotional intelligence among normal female students and those with social learning disabilities. To achieve the objectives of the study, the author prepared and applied the emotional intelligence scale and Hugh M. Bell Adjustment Inventory (1934). The validity of the two scales were verified on a sample of (120) female students, selected from (5) elementary schools. The study resulted that the level of emotional intelligence among normal female students and those with social learning disabilities was above median, the results also showed the presence of positive statistically significant correlation between both emotional intelligence, psychological adjustment and academic achievement among the normal female students (without social learning difficulties), with no statistically significant correlation between them among the students with social learning disabilities. The study also indicated that there were statistically significant differences between normal students and those with social learning disabilities in their performance on the scale of emotional intelligence (EQ-i) in favor of the normal on all dimensions of the scale and the total scale, while the dimension of sympathy didn't show any statistically significant differences. At last, some recommendations have been made
\end{abstract}


according to the findings of the study.

Keywords: Teachers of deaf students, Additional educational support, Qatar

\section{Introduction}

Although learning difficulties were primarily known as academic difficulties, they have numerous effects and dimensions beyond the academic fields. Such effects and dimensions revolve around problems and difficulties of social and emotional behavior of that group. Many researchers believe that it is inadequate to deal with academic difficulties away from the social and emotional effects resulting from such difficulties (Kavale\&Forness, 1996)

Al-Buhairi(2012), quoted from Bandura, points that "social learning difficulties are due to recurring school failure, not reinforcing the accepted social behaviors, and encouraging the good work." Low achievement suffered by people with learning difficulties might result in some emotional problems like exclusion from peers, low self-concept, and poor social communication (Gardner and Qualter 2010). Children with learning difficulties have high rates of behavioral and emotional problems four times more than the normal ones (Schachter, Pless, \&Bruck, 1991).

It is noted that most of studies that have dealt with this group focused on its negative aspects and ignored the positive ones, in spite of the fact that positive psychology studies have increased in recent years especially the eighties of the last century. Therefore, Studies paid more attention to Emotional Intelligence since it is one of the variables of positive preventive psychology for utilizing the positive side of emotions and feelings in addressing many issues of concern to the individual, family and society. It also means the potential exploitation of both emotion and intelligence for the human mental health and to achieve the quality of psychological adjustment.

Emotional Intelligence according to the Bar-On model of emotional-social intelligence is defined as " $a$ cross-section of interrelated emotional and social competencies, skills and facilitators that determine how effectively we understand and express ourselves, understand others and relate with them, and cope with daily demands. (Rizkallah, 2006, p. 61)

Goleman (1995) pointed that an individual's Emotional Intelligence skills constitute the first basis in achieving psychological adjustment, and control over the tension and negative emotions. It is also considered a key factor in the success of the individual and his or her superiority. Therefore, the importance of Emotional Intelligence is considered a new introduction to develop the individuals' abilities, prepare them for a better life and help them fully invest their abilities.

There are many studies that addressed the relationship between Emotional Intelligence and learning difficulties like the study of Reiff (2001), which aims at identifying the relationship between learning difficulties and gender and their relationship with Emotional Intelligence. The study sample consisted of (128) male and female students. The results of the study showed statistically significant differences between normal students and students with 
learning difficulties in their performance on the Emotional Intelligence scale (EQ-i) in favor of normal students. The results of the study also showed the existence of differences between males and females within social skills in favor of females. The study of Perston (2010) aims at investigating the relationship between Emotional Intelligence and academic success in the middle stage of students with learning difficulties. The findings of the study have revealed that the students with above average performance on the Emotional Intelligence scale got higher scores in language. The study also indicated that students, who achieved academic success, were better in managing stress. Al-Owady (2013) conducted a study to detect differences in performance on the dimensions of Emotional Intelligence among normal students and those with learning difficulties according to the variables of gender and age. The study sample consisted of (991) students. The results indicated that there were statistically significant differences between normal students and those with learning difficulties on all the sub dimensions, except for self-efficiency, and total scores of the scale in favor of normal students.

By the same token, some studies were conducted to reveal the relationship between Emotional Intelligence and psychological and social adjustment. The study of Abdel Fattah (2001) aimed to investigate the effectiveness of a training program of Emotional Intelligence on the adjustment of university students. The results of the study revealed that there is a great relationship between Emotional Intelligence and adjustment among female students. Abzahk (2010) investigated the effect of an educational program based on Goleman Emotional Intelligence Theory on improving social adjustment and achievement among a sample of students with learning difficulties in Jordan. The study sample consisted of (24) male and female students with learning difficulties enrolled in the three primary grades (3, 4 and 5). The results of the study showed statistically significant differences between the experimental group and the control group on the social adjustment scale in favor of the experimental group, while there was no statistically significant difference on the academic achievement variable. Aldiasty (2010) conducted a study about the Emotional Intelligence and its relationship to psychosocial and social adjustment among a sample of children (13-16 years). The study concluded that the high level of Emotional Intelligence gives an individual psychosocial and social adjustment with social, family, or school situations. Albalwy (2004) conducted a study to identify the relationship between Emotional Intelligence and psychological adjustment and social skills among a sample of female students in the Faculty of Education in Tabuk. The study sample consisted of (290) students. The findings of the study revealed that there was a statistically significant positive relationship between the scores of students on the Emotional Intelligence scale dimensions and their scores on the Psychological Adjustment Scale.

After accessing literature review pieces, it can be concluded that there is an agreement that people with learning difficulties are less able to react constructively and positively with difficult social situations. They are also less aware of the negative consequences of their reactions compared to their normal peers. Such studies drew attention to the importance of the role of Emotional Intelligence in the academic achievement and in achieving psychological adjustment of the individual. Emotional Intelligence now is of as great importance as mental intelligence, since it enables the individual to be more adjusted with 
himself/herself. It serves as the bridge that leads to success in various fields of life. Therefore, there was an urgent need to conduct this study to convey the relationship between Emotional Intelligence and psychological adjustment and academic achievement among female students with social learning difficulties and to find the statistically significant differences between them and their normal peers in Najran, KSA.

\section{Statement of the Problem}

The researcher believes that although the variables of the study "emotional intelligence and psychological adjustment" have been addressed in several Arab psychological studies, few studies addressed the category of social learning difficulties both at the level of psychological studies in general and Saudi Arabia in particular. Therefore, the current study attempts to investigate the relationship between emotional intelligence, psychological adjustment and academic achievement among a sample of female students with and without social learning difficulties in the city of Najran. The problem of the study shown in the following questions:

1. What is the degree of Emotional Intelligence among normal female students and those with social learning difficulties in Najran?

2. Is there any statistically significant correlation between the scores of normal female students and those with social learning difficulties in Emotional Intelligence and their scores on psychological adjustment and academic achievement?

3. Are there statistically significant differences between normal female students and those with social learning difficulties in Emotional Intelligence and psychological adjustment according to academic achievement?

\section{Hypotheses}

In the light of the theoretical framework and literature review mentioned above, Hypotheses can be formulated as follows:

1. Female students with and without social learning difficulties in Najran are characterized by moderate emotional intelligence.

2. There is no statistically significant correlation between the scores of normal students and those with social learning difficulties in Emotional Intelligence and their scores on psychological adjustment and academic achievement.

3. There are no statistically significant differences between normal female students and those with social learning difficulties on Emotional Intelligence and psychological adjustment

\section{Objectives}

1. Identifying the Emotional Intelligence levels among female students with and without social learning difficulties in Najran.

2. Identifying the correlation relationship between Emotional Intelligence and both the psychological adjustment and academic achievement among the participants. 


\section{Macrothink}

International Journal of Learning and Development

ISSN 2164-4063

2016, Vol. 6, No. 3

3. Identifying the differences in both Emotional Intelligence and psychological adjustment among normal female students and those with social learning difficulties in Najran and their relationship with academic achievement.

\section{Significance}

The importance of the theoretical study lies in addressing the variables of Emotional Intelligence and psychological adjustment among students with social learning difficulties. Such variables are the most influential in the individual's behavior and in his/her communication with others. It also sheds the light on students with social learning difficulties in an attempt to help them find solutions for their psychological and academic problems. Such study will enrich the theoretical frameworks regarding the importance of Emotional Intelligence and the role played in adjusting the child with himself and his community. The study also will support contemporary trend in positive psychology according to the study of (Salovey\& Mayer,2002).

\section{Study terms and definitions}

\subsection{First: Emotional Intelligence}

The concept of Emotional Intelligence was introduced to reinforce integrative outlook between intelligence and emotions. Mayer (2000) confirmed that the personal mood affects the persons' thinking. The early nineties is considered the actual beginning of the use of the term Emotional Intelligence when Mayer \& Salovey (1997) described it as a kind of social intelligence that includes the ability to take control of emotions and feelings and distinguish between them. Shapiro (2005) pointed that the individual utilizes this information to direct his/her thought and behaviors. Emotional Intelligence defined by Baron (2000) as individual's awareness and control of his feelings and the feelings of others. It is the ability to stimulate one's motives in a good way. Abdullah (2002) indicated that Emotional Intelligence is the ability of an individual to express the positive and negative emotions in the context of relations between individuals. It also means the ability to show awareness and good attention to his own emotions, understanding and clearly formulating and regulating them according to his/her meticulous awareness of emotions of others that enable him to start positive relationships with them that can help him/her succeed in life. Bar-On (2006) defined Emotional Intelligence as a group of emotional-social skills that affect the overall ability of the individual to adapt with the circumstances surrounding him. Wu (2010) agrees with the above definitions, where she defined Emotional Intelligence as the ability of an individual to understand his feelings and emotions and to control, manage, and deal with, or utilizing and treating them.

\subsection{Dimensions of Emotional Intelligence}

Goleman (1995) suggested a model for emotional intelligence including five dimensions classified into two main components: (1) Personal components comprising three dimensions: Emotional Self-awareness, Self-Regulation and Self- Motivation. (2) Social components comprising two dimensions: Empathy and Social skills. 
Emotional Intelligence, in this study, defined as the degrees obtained by the participants on the Emotional Intelligence Scale prepared by the author to match primary stage female students with learning difficulties in KSA. The dimensions adopted in this study are self-awareness, Self-regulation, Motivation, Empathy, and Social skills.

\subsection{Secondly: Social Learning Difficulties}

Daniel (1981) indicates that there are three factors that contribute to identifying learning difficulties; namely, academic and developmental characteristics and social characteristics represented by immaturity of social skills. Kerr \& Nelson (1983) demonstrated that there are a large number of those who suffer from learning difficulties are characterized by social deficits represented in lack of cooperation and social competence. Lerner (2000) defines children with social learning difficulties as those children who do not interact positively with others, especially in the academic situations, and are lacking maintaining friendships with others because they lack social awareness and they are neglected and not accepted by others.

They are operationally defined as students with median intelligence, who do not suffer from any mental or sensory disabilities. They have a low academic achievement as well as social learning difficulties reflected in the difficulties in making friendships and family relations.

\subsection{Thirdly: Psychological Adjustment}

Adjustment is considered one of the basic concepts in mental health, since most of the behaviors of the individual whether successful or unsuccessful are just attempts to adjustment in order to reduce the tension suffered by the individual. Sound psychological adjustment paves for the principle of self-control, social moderation, flexibility and adaptability to the individuals in the community.

Taha,et al, (1993) define Psychological Adjustment as the primary criterion for achieving psychological and social normalness to the individual in the context of his/her relationship with the society. It includes reducing the tension aroused by the needs. Sufian (2004) defines it as the individual's satisfaction of his psychological needs, self-acceptance, enjoyment of tension-free life, free of conflicts and psychological disorders, enjoyment of intimate social relations, participation in social activities, and acceptance of the customs, traditions and values of society.

Psychological adjustment involves Personal and Emotional Adjustment, Social Adjustment, Family Adjustment, and School Adjustment.

The operational definition of psychological, social and academic adjustment is the sum of scores obtained by the student in the psychological, social and academic adjustment scale used in this study.

\subsection{Fourthly: Academic Achievement}

The author of the current study adopted the scores obtained by the students in the exams of the courses studied during the academic year 2014/2015. The author classified the students into two groups: (70\% and more) are high achievers and (69\% or less) are low achievers. 


\section{Methodology}

The current study adopted the descriptive correlational comparative method, which relies on identifying and describing the phenomena and the facts related to these phenomena in the current situation.

\subsection{Sampling}

The main study sample consisted of(120) female students enrolled in grade four, five, and six in primary stage. Their average age was $(6,7$ and 10) years with a standard deviation of (1.53) years. The sample consisted of (60) normal female students and (60) students with social learning difficulties. The participants were selected from (7) schools for primary education of the Ministry of Education in Najran for the academic year 2014/2015. Two schools were excluded from the sample for non-completion of the tests and standards applied to the sample, as shown in Table (1):

Table (1): the sample in terms of number

\begin{tabular}{|c|c|c|c|c|c|}
\hline School & Grades & $\begin{array}{l}\text { No. of } \\
\text { Students with } \\
\text { learning } \\
\text { difficulties }\end{array}$ & $\begin{array}{l}\text { No. of normal } \\
\text { students }\end{array}$ & Sum & Percentage \\
\hline \multirow{3}{*}{ The $8^{\text {th }}$ School } & Grade 4 & 6 & 6 & \multirow{3}{*}{30} & \multirow{3}{*}{$\% 25$} \\
\hline & Grade 5 & 5 & 5 & & \\
\hline & Grade 6 & 4 & 4 & & \\
\hline \multirow{3}{*}{ The $13^{\text {th }}$ School } & Grade 4 & 5 & 5 & \multirow{3}{*}{24} & \multirow{3}{*}{$\% 20$} \\
\hline & Grade 5 & 3 & 3 & & \\
\hline & Grade 6 & 4 & 4 & & \\
\hline \multirow{3}{*}{ The $32^{\text {nd }}$ School } & Grade 4 & 4 & 4 & \multirow{3}{*}{18} & \multirow{3}{*}{$\% 15$} \\
\hline & Grade 5 & 2 & 2 & & \\
\hline & Grade 6 & 3 & 3 & & \\
\hline \multirow{2}{*}{ Al Iskan School } & Grade 4 & 6 & 6 & \multirow{2}{*}{30} & \multirow{2}{*}{$\% 25$} \\
\hline & Grade 5 & 6 & 6 & & \\
\hline
\end{tabular}




\begin{tabular}{|l|l|l|l|l|l|}
\hline & Grade 6 & $\mathbf{3}$ & $\mathbf{3}$ & & \\
\hline \multirow{2}{*}{$\begin{array}{l}\text { Prince Mishaal } \\
\text { School }\end{array}$} & Grade 4 & $\mathbf{2}$ & $\mathbf{2}$ & & \\
\cline { 2 - 7 } & Grade 5 & $\mathbf{3}$ & $\mathbf{3}$ & $\mathbf{1 8}$ & \%15 \\
\cline { 2 - 7 } & Grade 6 & $\mathbf{4}$ & $\mathbf{4}$ & $\mathbf{1 2 0}$ & $\mathbf{\% 1 0 0}$ \\
\hline Total & & $\mathbf{6 0}$ & $\mathbf{6 0}$ & \\
\hline
\end{tabular}

\subsection{Instruments}

\subsubsection{Emotional Intelligence Scale}

The Emotional Intelligence Scale consisted of (42)paragraphs distributed into five dimensions: self-awareness ( 8 paragraphs), self-regulation (10 paragraphs), motivation (9 paragraphs), empathy (8 paragraphs), and social skills (7 paragraphs). The five-point Likert scale adopted in this study: "always, often, sometimes, rarely and never." The respondents' rates will be " $4,3,2,1$ and 0 ", respectively, if the significance of the paragraph was positive. If the significance of the paragraph was negative, the respondents' rates will be " $0,1,2,3$ and 4", respectively. The level of Emotional Intelligence of the student is calculated by the total scores obtained in the scale.

Eight referees and reviewers who are faculty in Education, Psychology, and Special Education at the University of Najran evaluated the appropriateness of the paragraphs for the dimensions they belong to and for the purposes of the study, the clarity of the statements, and the extent of its application to students with learning difficulties. Based on the reviewers' comments, the author made the necessary modifications. Therefore, the final draft of the scale included(38)paragraphs.

The scale was applied to a pilot sample of (30) students from the upper grades in primary school to calculate the reliability and validity as follows:

\subsubsection{Validity}

The internal validity of the scale: Correlation coefficients calculated between the scores obtained by respondents for each paragraph and the total score of the scale, as shown in the following table. 


\section{Macrothink}

International Journal of Learning and Development ISSN 2164-4063 2016, Vol. 6, No. 3

Table (2): Correlation coefficients between paragraphs and the total emotional intelligence scale

\begin{tabular}{|l|l|l|l|l|l|l|l|l|l|}
\hline \multicolumn{2}{|l|}{ Self-awareness } & \multicolumn{2}{l|}{ Self-regulation } & \multicolumn{2}{l|}{ Motivation } & \multicolumn{2}{l|}{ Empathy } & \multicolumn{2}{l|}{ Social skills } \\
\hline $\begin{array}{l}\text { No. of } \\
\text { paragr } \\
\text { aph }\end{array}$ & $\begin{array}{l}\text { Correlatio } \\
\text { coefficient } \\
\text { s }\end{array}$ & $\begin{array}{l}\text { No. } \\
\text { of } \\
\text { para } \\
\text { grap } \\
\text { h }\end{array}$ & $\begin{array}{l}\text { Correlati } \\
\text { on } \\
\text { coefficie } \\
\text { nts }\end{array}$ & $\begin{array}{l}\text { No. } \\
\text { of } \\
\text { para } \\
\text { grap } \\
\text { h }\end{array}$ & $\begin{array}{l}\text { norrelatio } \\
\text { coefficient } \\
\text { s }\end{array}$ & $\begin{array}{l}\text { No. } \\
\text { of } \\
\text { para } \\
\text { grap } \\
\text { h }\end{array}$ & $\begin{array}{l}\text { Correlati } \\
\text { on } \\
\text { coefficie } \\
\text { nts }\end{array}$ & $\begin{array}{l}\text { No. } \\
\text { of } \\
\text { para } \\
\text { grap } \\
\text { h }\end{array}$ & $\begin{array}{l}\text { Correlatio } \\
\text { coefficient } \\
\text { s }\end{array}$ \\
\hline $\mathbf{1}$ & $* * \mathbf{0 . 3 9 2}$ & $\mathbf{2}$ & $* * \mathbf{0 . 3 7 9}$ & $\mathbf{3}$ & $* * \mathbf{0 . 3 6 4}$ & $\mathbf{4}$ & $* * \mathbf{0 . 3 6 1}$ & $\mathbf{5}$ & $* * \mathbf{0 . 4 3 4}$ \\
\hline $\mathbf{6}$ & $* * \mathbf{0 . 4 3 5}$ & $\mathbf{7}$ & $* * \mathbf{0 . 5 0 6}$ & $\mathbf{8}$ & $* * \mathbf{0 . 4 8 1}$ & $\mathbf{9}$ & $* * \mathbf{0 . 4 9 2}$ & $\mathbf{1 0}$ & $* * \mathbf{0 . 3 8 2}$ \\
\hline $\mathbf{1 1}$ & $* * \mathbf{0 . 5 4 2}$ & $\mathbf{1 2}$ & $* * \mathbf{0 . 4 4 3}$ & $\mathbf{1 3}$ & $* * \mathbf{0 . 6 3 7}$ & $\mathbf{1 4}$ & $* * \mathbf{0 . 4 3 6}$ & $\mathbf{1 5}$ & $* * \mathbf{0 . 5 1 6}$ \\
\hline $\mathbf{2 1}$ & $* * \mathbf{0 . 5 4 3}$ & $\mathbf{1 7}$ & $* * \mathbf{0 . 6 7 5}$ & $\mathbf{1 8}$ & $* * \mathbf{0 . 4 4 5}$ & $\mathbf{1 9}$ & $* * \mathbf{0 . 5 8 5}$ & $\mathbf{2 0}$ & $* * \mathbf{0 . 5 3 5}$ \\
\hline $\mathbf{2 6}$ & $* * \mathbf{0 . 6 1 4}$ & $\mathbf{2 7}$ & $* * \mathbf{0 . 5 3 0}$ & $\mathbf{2 8}$ & $* * \mathbf{0 . 5 3 3}$ & $\mathbf{2 9}$ & $* * \mathbf{0 . 5 1 2}$ & $\mathbf{3 0}$ & $* * \mathbf{0 . 6 3 2}$ \\
\hline $\mathbf{3 1}$ & $* * \mathbf{0 . 5 6 0}$ & $\mathbf{3 2}$ & $* * \mathbf{0 . 6 5 4}$ & $\mathbf{3 3}$ & $* * \mathbf{0 . 6 7 5}$ & $\mathbf{3 4}$ & $* * \mathbf{0 . 6 7 0}$ & $\mathbf{3 5}$ & $* * \mathbf{0 . 6 6 9}$ \\
\hline $\mathbf{3 6}$ & $* * \mathbf{0 . 6 2 3}$ & $\mathbf{3 7}$ & $* * \mathbf{0 . 5 6 3}$ & $\mathbf{3 8}$ & $* * \mathbf{0 . 6 7 3}$ & & & $\mathbf{2 4}$ & $* * \mathbf{0 . 5 7 3}$ \\
\hline
\end{tabular}

** Significance level 0.01

Table (2) indicates that values of correlation coefficient ranged from $(0.0361-0.675)$ statistically significant at 0.01 , which verifies the validity of scale's paragraphs.

The internal validity of the dimensions of the scale: Correlation coefficients calculated between the scores obtained from each dimension of the scale and the total score of the scale, as shown in table (3): 
Table (3): Validity of internal consistency for the scale of emotional intelligence

\begin{tabular}{|l|l|}
\hline Dimension & $\begin{array}{l}\text { Correlation } \\
\text { coefficient }\end{array}$ \\
\hline Self-awareness & $* * \mathbf{0 . 9 1 2}$ \\
\hline Self-regulation & $* * \mathbf{0 . 8 9 9}$ \\
\hline Motivation & $* * \mathbf{0 . 9 2 7}$ \\
\hline Empathy & $* * \mathbf{0 . 9 3 2}$ \\
\hline Social skills & $* * \mathbf{0 . 9 2 0}$ \\
\hline
\end{tabular}

Table (3) indicated that values of correlation coefficient ranged between $(0.899-0.0927)$, statistically significant at $(0.01)$, which verifies the validity of the scale dimensions.

\subsubsection{Reliability of the scale}

T-value calculated by (test-retest) method to a pilot sample $(\mathrm{n}=30)$ with two weeks interval time. The value of " $T$ " was $(0.89)$ which means that the scale is highly reliable. The value of " $t$ " was calculated to estimate the internal validity using Spearman Brown formula, Cronbach's alpha coefficient, and Guttman coefficient.

Table (5): T-values by Spearman Brown formula, Cronbach's alpha coefficient, and Guttman coefficient

\begin{tabular}{|l|l|l|l|}
\hline Scale & $\begin{array}{l}\text { Spearman } \\
\text { Brown }\end{array}$ & Guttman & $\begin{array}{l}\text { Cronbach's } \\
\text { alpha }\end{array}$ \\
\hline $\begin{array}{l}\text { Emotional } \\
\text { Intelligence }\end{array}$ & $\mathbf{0 . 7 8}$ & $\mathbf{0 . 7 6}$ & $\mathbf{0 . 7 4}$ \\
\hline
\end{tabular}

\subsection{Psychological Adjustment Scale}

The author used Hugh M. Bell Adjustment Inventory (1934), with the aim of identifying the psychological adjustment level among students. It was made in Arabic by Negati (1960) and was developed by Altaher (1994). The final draft of the scale consisted of (47)paragraphs with three domains (psychological adjustment, social adjustment and school adjustment). Each domain consisted of (14) paragraphs except for the school adjustment, which consisted of (19) paragraphs. The responses (always - sometimes - rarely- never) take " $3,2,1$ and 0", respectively, if the significance of the paragraph was positive. If the significance of the paragraph was negative, the responses will be as follows " $0,1,2,3$ ", respectively. The level of student's adjustment is calculated by the total scores obtained. The higher the score is, the 
lower level of adjustment obtained and vice versa. The total score of the scale was (94). The scale includes (six positively significant paragraphs) numbered as (17-18-20-28-37-40) and the rest of the paragraphs are negative.

\subsubsection{The psychometric characteristics of the scale}

The developer of the scale verified the psychometric characteristics of the scale that demonstrated high coefficients of reliability and validity after applying it to a sample of university students. The correlation coefficient between the total score of the scale and sub scores calculated. The validity and reliability of the scale and the reliability of its three dimensions were verified by (test-retest) method and Cronbach's alpha on a pilot sample. The values of cronbach's alpha reliability coefficient were $(0,745 \cdot 0,865 \cdot 0.754)$ for each dimension, respectively. The total score for the reliability of the scale was $(0.896)$ which confirmed great reliability of the final draft of the scale.

\subsubsection{Internal validity of the scale}

The values of correlation coefficients were calculated by the total score of each dimension and the total score of the scale, as shown in table (5).

Table (5): Internal validity of Psychological Adjustment Scale

\begin{tabular}{|l|l|l|}
\hline Domain & $\begin{array}{l}\text { Correlation } \\
\text { coefficient }\end{array}$ & Significance \\
\hline $\begin{array}{l}\text { Psychological } \\
\text { adjustment }\end{array}$ & $\mathbf{0 . 9 0 3}$ & Significant \\
\hline Social adjustment & $\mathbf{0 . 6 8 4}$ & Significant \\
\hline $\begin{array}{l}\text { School } \\
\text { adjustment }\end{array}$ & $\mathbf{0 . 5 5 0}$ & Significant \\
\hline
\end{tabular}

Table (5) indicated that correlation coefficient ranged between (0.550) and (0.903), statistically significant at $(0.05)$.

7.3.3 The reliability of psychological adjustment scale

Reliability calculated through Spearman' split half method, Cronbach's alpha coefficient, and Guttman coefficient. Table (6) shows the values of reliability coefficients to measure social adjustment. 
Table (7): Reliability coefficient to Psychological adjustment scale

\begin{tabular}{|l|l|l|l|l|}
\hline S. & Scale & $\begin{array}{l}\text { No. of } \\
\text { paragraphs }\end{array}$ & Cronbach's alpha & Spearman coefficient \\
\hline $\mathbf{1}$ & $\begin{array}{l}\text { Psychological } \\
\text { adjustment }\end{array}$ & $\mathbf{1 4}$ & .750 & .650 \\
\hline $\mathbf{2}$ & Social adjustment & $\mathbf{1 4}$ & .810 & .840 \\
\hline $\mathbf{3}$ & School adjustment & $\mathbf{1 9}$ & .700 & .650 \\
\hline \multicolumn{2}{|c|}{ Total } & 47 & .860 & .740 \\
\hline
\end{tabular}

\section{Results}

\subsection{First: The first hypothesis}

"Female students with and without social learning difficulties in Najran are characterized by moderate emotional intelligence." To verify the first hypothesis, Kolmogrov Sminov Test was conducted to check if the scores of Emotional Intelligence for normal students and students with social learning difficulties are normal or not.

Table (7): One Sample Kolmogrov Sminov Test

\begin{tabular}{|l|l|l|l|l|}
\hline Variable & Mean & $\begin{array}{l}\text { Standard } \\
\text { Deviation }\end{array}$ & $\begin{array}{l}\text { Kolmogrov } \\
\text { Sminov }\end{array}$ & الدلالة المعنوية \\
\hline Normal female students & $\mathbf{1 0 6 . 6 5}$ & $\mathbf{6 . 3 9 6}$ & $\mathbf{0 . 9 9 3}$ & $\mathbf{0 . 2 7 8}$ \\
\hline With social learning difficulties & $\mathbf{9 5 . 3 6 6}$ & $\mathbf{5 . 9 4 0}$ & $\mathbf{0 . 6 8 3}$ & $\mathbf{0 . 7 3 9}$ \\
\hline
\end{tabular}

Table (7) pointed that $(Z=0.993)$ with significant value of $(0.278)$; it is more than $(0.05)$ among normal students, which indicates that their rates in Emotional Intelligence are normal. This means that $(68 \%)$ of the rates of normal students in Emotional Intelligence are within (100.254 to 113.046$)$.

The table also indicated that $(Z=0.683)$ at a significant value of $(0.739)$ that is more than (0.05) for female students with social learning difficulties, which indicates that their rates in Emotional Intelligence are normal. This means that (68\%) of the rates of students with social learning difficulties in Emotional Intelligence are within (89.426 to 101.306).

The following figure indicates the moderate distribution to the rates of emotional intelligence for female students with and without social learning difficulties, as shown in figure (1): 

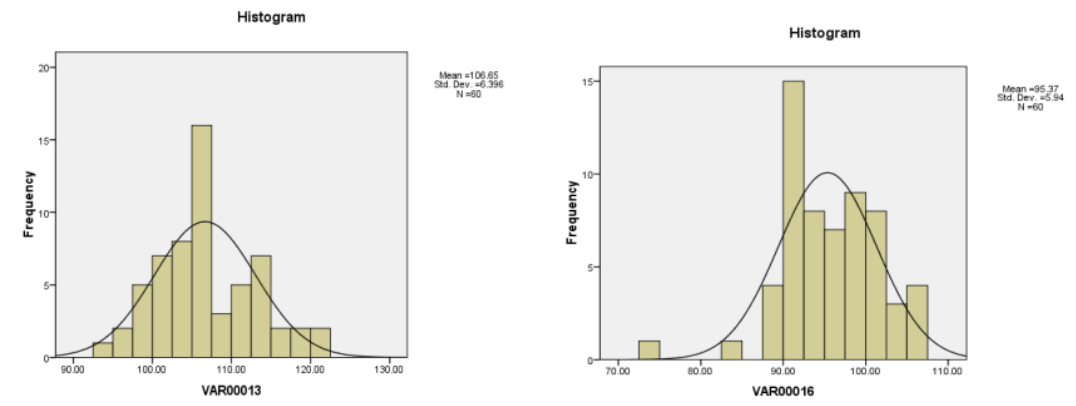

\subsection{The second hypothesis:}

"There is no statistically significant correlation between the scores of normal students and those with social learning difficulties in Emotional Intelligence and their scores on psychological adjustment and academic achievement" To verify the second hypothesis, Pearson correlation coefficient between the two variables, as illustrated in table (8) and (9).

Table (8): Pearson correlation coefficient between emotional intelligence and psychological adjustment for normal female students and those with social learning difficulties

\begin{tabular}{|c|c|c|c|c|c|}
\hline & Variable & Mean & $\begin{array}{l}\text { Correlation } \\
\text { coefficient }\end{array}$ & $\begin{array}{l}\text { Significance } \\
\text { level }\end{array}$ & \\
\hline \multirow{2}{*}{$\begin{array}{l}\text { With social } \\
\text { learning } \\
\text { difficulties }\end{array}$} & $\begin{array}{l}\text { Emotional } \\
\text { intelligence }\end{array}$ & 95.366 & \multirow{2}{*}{0.029} & \multirow{2}{*}{0.826} & \multirow{2}{*}{ Non-significant } \\
\hline & $\begin{array}{l}\text { Psychological } \\
\text { adjustment }\end{array}$ & 24866 & & & \\
\hline \multirow{2}{*}{$\begin{array}{l}\text { Normal female } \\
\text { students }\end{array}$} & $\begin{array}{l}\text { Emotional } \\
\text { intelligence }\end{array}$ & 106.65 & \multirow{2}{*}{0.276} & \multirow{2}{*}{0.033} & \multirow{2}{*}{ Non-significan } \\
\hline & $\begin{array}{l}\text { Psychological } \\
\text { adjustment }\end{array}$ & 262.5 & & & \\
\hline
\end{tabular}

Table (8) showed that the statistical significance value of the correlation coefficient between Emotional Intelligence and psychological adjustment for students with social learning difficulties is (0.826), more than (0.05). This indicates that the value of Pearson correlation coefficient is not statistically significant, very close to zero, which means there is no correlation between the two variables. Therefore, we accept the null hypothesis that "there is no correlation between the scores of Emotional Intelligence for students with social learning difficulties and their rates in psychological adjustment." The correlation coefficient is (0.029) and this might partially achieve the second hypothesis. The statistical significance value of the correlation coefficient of the normal students was (.033), less than (0.05). This indicates 


\section{Macrothink}

International Journal of Learning and Development

ISSN 2164-4063

2016, Vol. 6, No. 3

that there is a positive correlation between the rates of Emotional Intelligence for normal students and their rates in psychological adjustment.

Table (9): Pearson correlation coefficient between emotional intelligence and achievement among female students with and without social learning difficulties

\begin{tabular}{|c|c|c|c|c|c|c|}
\hline & & Variable & Mean & $\begin{array}{l}\text { Correlation } \\
\text { coefficient }\end{array}$ & $\begin{array}{l}\text { Significance } \\
\text { level }\end{array}$ & \\
\hline \multirow{2}{*}{$\begin{array}{l}\text { Female } \\
\text { with } \\
\text { learning } \\
\text { difficulties }\end{array}$} & \multirow{2}{*}{$\begin{array}{r}\text { students } \\
\text { social }\end{array}$} & $\begin{array}{l}\text { Emotional } \\
\text { intelligence }\end{array}$ & 95.366 & \multirow[t]{2}{*}{0.355} & \multirow[t]{2}{*}{0.121} & \multirow[t]{2}{*}{ Non-significan } \\
\hline & & Achievement & 0.057 & & & \\
\hline \multirow{2}{*}{$\begin{array}{l}\text { Without } \\
\text { learning } \\
\text { difficulties }\end{array}$} & \multirow[t]{2}{*}{ social } & $\begin{array}{l}\text { Emotional } \\
\text { intelligence }\end{array}$ & 106.65 & \multirow[t]{2}{*}{0.373} & \multirow[t]{2}{*}{0.003} & \multirow[t]{2}{*}{ Significant } \\
\hline & & Achievement & 2.48 & & & \\
\hline
\end{tabular}

Table (9) reveals that the statistical significance value of the correlation coefficient between Emotional Intelligence and academic achievement for students with social learning difficulties is (0.121), more than (0.05), which indicates that the value of Pearson correlation coefficient is not statistically significant. Therefore, we accept the null hypothesis that "there is no correlation between the rates of Emotional Intelligence for students with social learning difficulties and their scores in academic achievement, which might partially achieve the second hypothesis. The statistical significance value of the correlation coefficient between academic achievement and Emotional Intelligence for the normal students was (.033), less than (0.05). This indicates that there is a positive correlation between Emotional Intelligence and academic achievement among normal female students, which didn't partially achieve the second hypothesis.

\subsection{The third hypothesis}

"There are no statistically significant differences between normal female students and those with social learning difficulties on Emotional Intelligence and psychological adjustment" To verify the third hypothesis, T-Test was conducted for two independent samples after checking the application of the test conditions to grades as shown in table (10). 
A- The dimensions of emotional intelligence:

Table (10): T-test results between the score means of female students with and without social learning difficulties in dimensions of emotional intelligence

\begin{tabular}{|c|c|c|c|c|c|c|}
\hline Variable & Group & Mean & St. D & T-value & $\begin{array}{l}\text { Sig. } \\
\text { level }\end{array}$ & Significance \\
\hline \multirow[t]{2}{*}{ Self-awareness } & $\begin{array}{l}\text { With } \\
\text { difficulties } \\
\mathrm{N}=60\end{array}$ & 18.466 & 2.593 & \multirow[t]{2}{*}{3.151} & \multirow[t]{2}{*}{0.002} & \multirow[t]{2}{*}{ Significant } \\
\hline & Without $\mathrm{N}=60$ & 19.900 & 2.384 & & & \\
\hline \multirow[t]{2}{*}{ Empathy } & $\begin{array}{l}\text { With } \\
\text { difficulties } \\
\mathrm{N}=60\end{array}$ & 20.95 & 2.645 & \multirow[t]{2}{*}{0.109} & \multirow[t]{2}{*}{0.913} & \multirow[t]{2}{*}{ Non-sig. } \\
\hline & Without $\mathrm{N}=60$ & 20.90 & 2.362 & & & \\
\hline \multirow[t]{2}{*}{ Self-regulation } & $\begin{array}{l}\text { With } \\
\text { difficulties } \\
\mathrm{N}=60\end{array}$ & 6.883 & 0.993 & \multirow[t]{2}{*}{2.134} & \multirow[t]{2}{*}{0.035} & \multirow[t]{2}{*}{ Significant } \\
\hline & Without $\mathrm{N}=60$ & 7.2833 & 1.059 & & & \\
\hline \multirow[t]{2}{*}{ Motivation } & $\begin{array}{l}\text { With } \\
\text { difficulties } \\
\mathrm{N}=60\end{array}$ & 23.000 & 2.201 & \multirow[t]{2}{*}{0.338} & \multirow[t]{2}{*}{0.736} & \multirow[t]{2}{*}{ Significant } \\
\hline & Without $\mathrm{N}=60$ & 23.133 & 2.119 & & & \\
\hline \multirow[t]{2}{*}{ Social skills } & $\begin{array}{l}\text { With } \\
\text { difficulties } \\
\mathrm{N}=60\end{array}$ & 26.006 & 4.814 & \multirow[t]{2}{*}{11.594} & \multirow[t]{2}{*}{0.000} & \multirow[t]{2}{*}{ Significant } \\
\hline & Without $\mathrm{N}=60$ & 35.433 & 3.997 & & & \\
\hline \multirow[t]{2}{*}{ Total } & $\begin{array}{l}\text { With } \\
\text { difficulties } \\
\mathrm{N}=60\end{array}$ & 95.366 & 6.396 & \multirow[t]{2}{*}{10.013} & \multirow[t]{2}{*}{0.000} & \multirow[t]{2}{*}{ Significant } \\
\hline & Without $\mathrm{N}=60$ & 106.650 & 5.940 & & & \\
\hline
\end{tabular}




\section{Macrothink}

Table (10) showed that there were statistically significant differences between female students without social learning difficulties (normal students) and those with social learning difficulties on all dimensions of Emotional Intelligence in favor of normal students except for the dimension of sympathy, where there were no statistically significant differences between them.

\section{$B$-The dimensions of psychological adjustment:}

T-Test was conducted to check the statistical significance of the differences between normal students and those with social learning difficulties on all dimensions of psychological adjustment and the total score, as shown in table (11).

Table (11): T-test results between the score means of female students with and without social learning difficulties in the dimensions of psychological adjustment

\begin{tabular}{|c|c|c|c|c|c|c|}
\hline Dimension & Group & Mean & St. D & T-value & Sig. level & Significance \\
\hline \multirow{2}{*}{$\begin{array}{l}\text { Psychological } \\
\text { adjustment }\end{array}$} & $\begin{array}{l}\text { With } \\
\text { difficulties } \\
\mathrm{N}=60\end{array}$ & 85.783 & 6.812 & \multirow{2}{*}{3.995} & \multirow{2}{*}{0.000} & \multirow{2}{*}{ Significant } \\
\hline & $\begin{array}{l}\text { Without } \\
\mathrm{N}=60\end{array}$ & 89.966 & 4.402 & & & \\
\hline \multirow{2}{*}{$\begin{array}{l}\text { Social } \\
\text { adjustment }\end{array}$} & $\begin{array}{l}\text { With } \\
\text { difficulties } \\
\mathrm{N}=60\end{array}$ & 80.166 & 5.149 & \multirow{2}{*}{8.903} & \multirow{2}{*}{0.000} & \multirow{2}{*}{ Significant } \\
\hline & $\begin{array}{l}\text { Without } \\
N=60\end{array}$ & 86.750 & 2.508 & & & \\
\hline \multirow{2}{*}{$\begin{array}{l}\text { School } \\
\text { adjustment }\end{array}$} & $\begin{array}{l}\text { With } \\
\text { difficulties } \\
\mathrm{N}=60\end{array}$ & 83.516 & 4.481 & \multirow{2}{*}{4.705} & \multirow{2}{*}{0.000} & \multirow{2}{*}{ Significant } \\
\hline & $\begin{array}{l}\text { Without } \\
N=60\end{array}$ & 85.833 & 3.122 & & & \\
\hline \multirow{2}{*}{ Total } & $\begin{array}{l}\text { With } \\
\text { difficulties } \\
\mathrm{N}=60\end{array}$ & 248.466 & 8.49 & \multirow{2}{*}{9.683} & \multirow{2}{*}{0.000} & \multirow{2}{*}{ Significant } \\
\hline & $\begin{array}{l}\text { Without } \\
N=60\end{array}$ & 262.55 & 7.40 & & & \\
\hline
\end{tabular}




\section{MInstitute Macrothink $^{m}$}

International Journal of Learning and Development

ISSN 2164-4063

2016, Vol. 6, No. 3

Table (11) indicated that there were statistically significant differences between female students with and without social learning difficulties in all dimensions of psychological adjustment in favor of normal students, thus the third hypothesis wasn't achieved.

\section{Discussion}

\subsection{With regard to the first hypothesis}

Based on the results of the first hypothesis, which showed that $(68 \%)$ of the rates of normal students in Emotional Intelligence ranged from (100.254) to (113.046) and (68\%) of the rates of students with social learning difficulties in Emotional Intelligence ranged from (89.426) to (101.306). It can be concluded that the level of Emotional Intelligence among the participants is above median, which means that they enjoy good emotional intelligence. Both of the two groups are from the same social environment, which leads to convergence of thoughts, emotions, and feelings. Such convergence, in results, can be explained in the light of the nature of the school environment, as it is a social environment, where students learn social communication skills, making of friendships, and how to adjust with others, since the skills of Emotional Intelligence can be learned and improved through continuous interaction and the successful adjustment between the individual and the environment. This given result might be due to the activities practiced in the school, which reinforces the Emotional Intelligence skills of the students through interaction with others.

Such result is consistent with Crick (2002), which concluded that students with learning difficulties demonstrated above median performance on the Emotional Intelligence scale. It also agreed with several studies such as the study of Perston (2010), Alabboushi (2009), and Qumash, et al (2013) which concluded that students with learning difficulties have all the dimensions of Emotional Intelligence but to varying degrees.

\subsection{With regard to the second hypothesis}

\subsubsection{Explaining the results of the first part of the $2^{\text {nd }}$ hypothesis}

Based on results of the second hypothesis, it can be concluded that there is a positive correlation between Emotional Intelligence and psychological adjustment with all its dimensions for normal students, i.e. the more normal students have emotional intelligence, the more they have social adjustment and vice versa. Such result can be explained in the light of Emotional Intelligence components, which include self-awareness which is considered the basis of self-confidence and the ability to understand the circumstances of life and cope with it logically and work effectively under pressure. It is also the basis of self-motivation to overcome anxiety and resist frustration to feel satisfaction and have psychological adjustment. The person, who has a high degree of Emotional Intelligence and self-awareness, has a high ability to identify his true feelings, and express them in a manner consistent with his ideas and inclinations. This confirmed the results of Goleman (2000) that "what an individual has of Emotional Intelligence skills forms the primary basis for achieving psychological adjustment and control over the tension and negative emotions". Bar-On (2006) confirmed that those with high Emotional Intelligence are more adapted to life developments compared to people with low emotional intelligence. 


\section{$\triangle$ Macrothink}

The lack of correlation between Emotional Intelligence and psychological adjustment among students with social learning difficulties can be explained in the light of Alzayat (2007) that there are difficulties and certain pressures experienced by people with learning difficulties cause them emotional disorders that later on affect their personality.

The results of the current hypothesis have agreed with the studies of Agwa (2000) and Albalwy (2004), which showed statistically significant positive relationship between the scores of normal female students on the Emotional Intelligence scale dimensions and the total score, and their scores on the psychological adjustment scale. The results of the current study are partially consistent with the pieces of literature review such as Goda(2007)and Al-Buhairi(2012) in terms of the correlation between Emotional Intelligence and positive psychological variables like happiness.

9.2.2 Explaining the results of the second part of the $2^{\text {nd }}$ hypothesis:

There is a positive correlation between Emotional Intelligence and academic achievement among normal students and there is a lack of correlational relationship between them among students with social learning difficulties. This indicates that normal students enjoy a degree of emotional intelligence as well as academic achievement. Therefore, emotional intelligence skills must be integrated with cognitive intelligence skills to support excellence of performance. The results of such hypothesis can be explained in the light of Goleman (2000) that not only does Emotional intelligence have a positive effect on academic achievement but it also has positive effect on the lifelong success.

There is no doubt that the positive self-esteem helps manage emotions and control them, and this in turn helps increase concentration that leads to increase achievement. In addition, any deficiency in emotional intelligence skills can hinder the use of individuals' mental abilities. There is no doubt that individuals who combine high levels of both mental intelligence and emotional intelligence will be more capable of effective adjustment with life situations. (Shapiro, 2005)

The result of such study are consistent with the results of Abisamra (2000), Smith \&Hebatella (2000), Radhi (2001), Alakaishy (2003), Petrides, et al (2004), and Alabboushi (2009), which concluded that there is a positive statistically significant correlation between emotional intelligence and academic achievement, and that the dimensions of emotional intelligence have the ability to predict academic success.

The results of the current study are inconsistent with several studies like Martha \&George (2001), O’Connor \&Raymond (2003), Woitaszewski\&Aalsma (2004), Algendy (2006), and Almilli (2010), which concluded that there is no correlation between emotional intelligence and academic achievement. Their results showed that emotional intelligence does not strongly predict academic success.

With regard to the third hypothesis:

Based on results of the third hypothesis, it can be concluded that there are statistically significant differences at the level $(0.05)$ between the means of scores of normal female 
students and the mean scores of female students with social learning difficulties on the scale dimensions (Self-Awareness, Self-Regulation, Empathy, Motivation, and Social Skills), and its total score except for the domain of sympathy. Such differences were in favor of normal students, indicating that the female students with social learning difficulties were lacking emotional intelligence skills compared to normal female ones. The results of such hypothesis can be attributed to the nature and characteristics of female students with social learning difficulties. Kerr \& Nelson (1983) confirmed that a large number of those who suffer from learning difficulties are characterized by the social inability represented in lack of cooperation and social competence. Those with learning difficulties are also less aware of the potential negative consequences of their emotions compared to their normal peers. This is linked to the low academic achievement they have, since the low achievement is often accompanied by a decrease in the ability to establish social relationships.

The superiority of normal students over students with social learning difficulties in some emotional intelligence skills can be explained in light of the factors affecting the emotions, since emotions are considered a complex structure affected by several factors including family upbringing and school education. Some of the families and teachers of those with social learning difficulties might not give importance to emotional aspects in education and they pay attention to the cognitive side and academic achievement, which results in the child's precognition of his feelings and emotions, although scientists confirm that "academic success is positively associated with emotional intelligence." (Parker, 2004)

Statistical results have shown that there are no statistical differences between the two groups of the study on the sympathy dimension. This is due to the same nature females have, where the psychological and biological construction of the female represented in her kind emotions and feelings makes her always seek to emotional communication and empathy with others.

This result is consistent withReiff (2001) and Al-owady (2013), which demonstrated that there were statistically significant differences in emotional intelligence among normalfemale students and female students with social learning difficulties in favor of the normalones.

\section{Recommendations}

In the light of the findings of the current study, it recommends the following:

1. Designing activities based on life experience for students with social learning difficulties to develop their emotional intelligence skills, which have an impact on providing them with useful and important life skills such as emotion management skills, self-regulation, empathy, motivation, and social skills.

2. Paying attention to educational programs and curricula for the development of emotional intelligence skills because of their importance in developing individual's personality, as well as his academic achievement.

3. Paying attention to emotional intelligence in all stages of the individual's life because it adds to success in life and adjustment with others.

4. Conducting Further studies on the relationship of emotional intelligence with some 
variables of personality.

\section{Acknowledgements}

The author of the present study expresses her gratitude to Deanship of Scientific Research, Najran University, KSA, for funding this research project.

\section{References}

Goda, Amal (2007).Emotional intelligence and its relationship to happiness and self-confidence among students of Al-Aqsa University.Najah University Journal for Research - Humanities - Vol. 21, 3.

Alakaishy, Bushra (2003). Adjustment in the university environment and its relationship with future anxiety, $\mathrm{PhD}$ thesis, Al-Mustansiriya University, College of Education.

Albalwy, Khoula(2004).Emotional intelligence and its relationship to the Psychological Adjustment and social skills among a sample of students in the Faculty of Education for Girls in Tabuk.Unpublished MA Thesis, College of Education for Girls in Riyadh, King Saud University.

Aldiasty, Rasha (2010). Emotional intelligence and its relationship to psychological and social adjustment among a sample of children (12-16 years).Childhood Studies, Egypt, 14 (50), 235 - 236.

Rizk Allah, Randa (2006). The effectiveness of a training program on developing emotional intelligence skills, a pilot study in the schools of Damascus city on a sample of students of the sixth grade of primary education, Unpublished PhD thesis, Department of Psychology, Faculty of Education, University of Damascus, Syria.

Agwa, Abdelaal (2002). Emotional intelligence and its relationship with cognitive intelligence, age, academic achievement, and psychological Adjustment among university students.Journal of the Faculty of Education, University of Alexandria, Volume, 13, Issue (1), p 250-433.

Altaher, Abdul Rahman(1994).The relationship between Omdurman Islamic University students' attitudes towards university curricula and their psychosocial adjustment.Unpublished $\mathrm{PhD}$ thesis, the University of Omdurman.

Abdullah, Izzat (2002). Emotional intelligence and its relationship with motivation for the achievement for university students, the sixth conference of the Islamic guidance for Social Service, College of Education, Al-Azhar University.

Alowady, Alliya (2013). Differences in emotional intelligence among normal students and those with learning difficulties according to the variables of genderin Jordan, Journal of the Islamic University of Educational and Psychological Studies, Volume 21, issue 1, p 367 - p 399 January.

Taha et al. (1993).Encyclopedia of psychology and psychoanalysis, Dar Suad Al-Sabah, Kuwait. 


\section{Ml Macrothink}

International Journal of Learning and Development ISSN 2164-4063

Radi, Fawqiya (2001). Emotional intelligence and its relationship to academic achievement and the ability of innovative thinking among university students, Journal of the Faculty of Education, Mansoura University, No. (45). P 73 - 204.

Shapiro, Lawrence (2001). How to raise a child with a high EQ: Parents' guide to Emotional Intelligence. Saudi Arabia: Jarir Bookstore.

Al-Buhairi, Mohamed (2007). The development of Emotional intelligence to reduce the severity of some problems among children with behavioral disorders, Journal of Psychology, Vol. 17, No. 3, p 585-642.

Al-Buhairi, Mohamed (2012). Structural model of the relationship between emotional creativity and some variables concerning children with learning and social difficulties, Arabic studies in psychology (vol.11, issue 3: July), p 365-417. Association of psychologists, the Arab Republic of Egypt.

Qumash, et al. (2013). The dimensions of emotional intelligence prevailing among students with learning difficulties, and its impact on the type of learning difficulty, gender, and grade in Karak, Jordan, Najah University Journal for Research - Humanities, Volume 27, issue 4.

Sufian, Nabil (2004). Guide to the personal and psychological counseling, theory, Growth adjustment and disorders, $1^{\text {st }}$ edition, College of Education, Taiz University, Yemen.

Alabboushi, Nawal (2009), Emotional intelligence and its relationship to academic achievementamong female students at the University of Umm Al-Qura, Studies of Humanities and Social Sciences, Volume (3) edition (41) 781 - retrieved from http://www.gulfkids.com/pdf/Daka

Abisamra, N. (2000). The Relationship between Emotional Intelligence and Academic Achievement in Eleventh.Graders. Available at: http://members.PP.19Fortunecity.com/nadabs/researchintell2. Htm attention to task.Journal Learning Disability Quarterly,4(4),pp.407-413

Bar - On, R. (2006).The Bar - on model of emotionalsocial intelligence (ESI).Psicothema, Vol, (18), No (1),PP,(13-25) .

Baron, R. (2000) Emotional and social intelligence insights from the emotional quotient inventory: Hand book of emotional intelligence. Jossy - Bass Books, San Francisco.

Daniel, P. (1981). Self-recording during group instruction:Effects on Attention to Ask. doi: 10.2307/1510743 Learning Disability Quarterly November 1981 vol.

Gardner, K; Quallter, P. (2010).Concurrent and incremental Validity of three trait Emotional Intelligence measures.Australia Journal of Psychology, 62 (1), 5-13.

Goleman,C, D. (1995). Emotional Intelligence: Why It Can Matter More Than IQ. New York, A Bantam Book.

Kavale, K. \&Forness, S. (1996). Social skills deficits and LD: A meta-analysis. Journal of Learning Disabilities, 29, 226-237. 


\section{Macrothink}

International Journal of Learning and Development

ISSN 2164-4063 2016, Vol. 6, No. 3

Kerr, M.M. \& Nelson, C.M.(1983).Strategies for managing behavior problems in the classroom. Columbus, Ohio: Charles E. Merrill Publishing Company.

Lerner, J. (2000): Learning disabilities;Theories, diagnosis, and teaching

Martha, T. \& George, M. (2001). Emotional Intelligence: The effect of gender,GPA, ethnicity. Paper presented at the Annual Meeting of the Mid-South Educational Research Association. Mexico City, November 14-16.

Mayer, J. D., Salovey, P., \& Caruso, D. R. (2000).Models of emotional intelligence.In R. Sternberg (Ed.), Handbook of intelligence (pp. 396-420). New York: Cambridge University Press

Mayer, J. \&Salovey, P. (1997). What is Emotional Intelligence? In P. Salovey\&D.Sluyter (Eds.).Emotional Development and Emotional Intelligence.(Pp. 3-31), New York, Basic Books.

O'Connor, R. \& Little, I.(2003).Revisiting the Predictive Validity of Emotional Intelligence: Self-Report Versus Ability-Based Measures. Personality and Individual Differences, 35, 1893-1902.

Parker, J.D. (2004) Emotional intelligence and academic success: examining the transition from high school to university. Available(on-line)://A:EBSCOhost.Htm

Reiff, H.B. ,Hatzes, N.M. , Bramel, M.H. \& Gibbon, T. (2001),.the Relationship of LD and gender with Emotional Intelligence in the College Students. Journal of Learning Disabilities, 34, 66-78.

Petrides, K., Furnham, A., and Erickson, F.(2004). The Role of Trait Emotional Intelligence In Academic Performance And Deviant Behavior At School. Journal of Personality and Individual Differences, 36 (2), pp.267-276277-294.Psychology, 62, 5-13.

Salovey, P., Mayer, J. D., \& Caruso, D. (2002).The positive psychology of emotional intelligence.In C. R. Snyder \& S. J. Lopez (Eds.), Handbook of positive psychology (pp. 159-171). New York: Oxford University Press.

Schachter, D.C., pless, I.B., \&Bruck, M., (1991).The prevalence and correlates of behavior problems in learning disabled children. Canadian Journal of psychiatry,36 (6), 323-331.

Smith, W. Hebatella, E. (2000).The Typologies of successful students in the Core subjects of language Arts Mathematics, and Social studies using the theory of Emotional Intelligence in a High school Environment in Tennessee. Eric Database ED449190.

Woitaszewski, scott,A\&Aalsma, Matthew, C.,(2004).the contribution of emotional intelligence to the social and academic success of gifted adolescents as measured by the Multifactor emotional intelligence.ScaleAdolescent Version. (27) (1), pp. 6-25.

Wu, C. (2010).The relationship among leisure participation, Leisure satisfaction, and emotional intelligence among elementary school teachers in Northern Taiwan. PHD, University Incarnate of Word. 


\section{Macrothink}

International Journal of Learning and Development

ISSN 2164-4063

\section{Copyright Disclaimer}

Copyright for this article is retained by the author(s), with first publication rights granted to the journal.

This is an open-access article distributed under the terms and conditions of the Creative Commons Attribution license (http://creativecommons.org/licenses/by/3.0/). 